\title{
External Balance Correction: Depreciation or Protection?
}

OVER THE NEXT DECADE the U.S. noninterest current account will have to shift from a deficit of 3.9 percent of GNP in 1986 to balance or even a surplus. Is there a need for policy intervention to bring about the adjustment? If so, which method will maximize welfare: exchange depreciation, tariffs, quotas, voluntary export restraints, or a mix?

The first section of this paper sets out a conceptual framework for analyzing the trade deficit and explains why it must be improved. A number of arguments suggest that the deficit is no problem. One such argument is that deficits can be financed indefinitely; another is that while surpluses may ultimately be necessary, there is no need for policy intervention. My own view is that adjustment is in fact required and that, at the real exchange rate levels of early 1987, even allowing for lags, the adjustment will be insufficient unless there are major changes in the relative growth rates of demand here and abroad.

Subsequent sections review the policy options for encouraging adjustment, starting with a tariff. In reviewing the macroeconomic effects of tariffs I highlight the revenue effects and note that in general the effects on interest rates, prices, and exchange rates are dependent on the monetary rule. I explore the effects under a nominal income rule and offer simulation results to show the contractionary effects of tariffs on output. After some discussion of selective tariffs, quotas, and voluntary export restraints, I conclude that further dollar depreciation and competitive interest rate reductions are the preferable policy choices.

\section{A Framework}

Figure 1 focuses on two key variables in the U.S. economy, the fullemployment federal budget and the real exchange rate. For concreteness 
Figure 1. Internal and External Balance

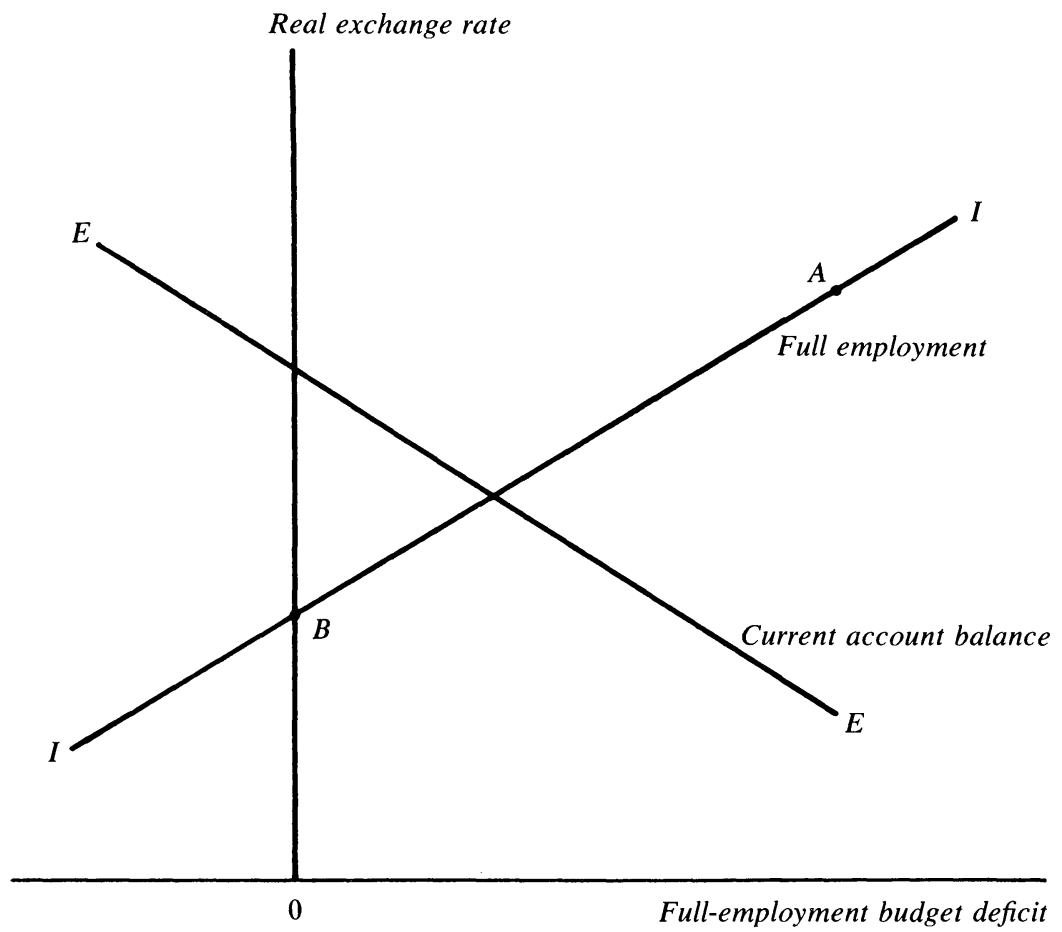

I assume that changes in the full-employment budget take the form of increased tax rates that affect the economy by reducing real spending at each level of output. The real exchange rate is measured as the ratio of home to competitors' prices in dollars, $P / e P^{*}$. For a given real interest rate, $r$, figure 1 shows the internal and external balance schedules. Along $E E$ the noninterest current account is in equilibrium: a real appreciation (a rise in $P / e P^{*}$ ) brings about a deficit and hence requires higher taxes and reduced spending to maintain external balance. ${ }^{1}$ Thus the area to the right of $E E$ represents current account deficits. Along $I I$ there is full employment: a fiscal expansion raises real spending and thus requires

1. It is assumed here that the noninterest current account (NICA) depends on disposable income. Hence changes in the full-employment budget affect both the demand for domestic goods and import spending. Letting $F$ denote the full-employment budget, have $Y^{*}=A\left(Y, F, r, P / e P^{*}\right)+N I C A\left(Y, F, r, P / e P^{*}\right)$ along $I I$ and $N I C A\left(Y, F, r, P / e P^{*}\right)=0$ along $E E$, where $Y^{*}$ is full employment output and $A$ is total real spending by domestic residents. It is assumed that a real depreciation improves the external balance. 
the compensating crowding out brought about by a real appreciation to maintain demand at the full-employment level. The area below the II schedule thus represents a situation of excess demand or overemployment.

Today the United States is at a point like A, with the economy near full employment and a large external deficit. My basic premise is that over the next decade the full-employment budget deficit must be much reduced-for graphical concreteness, to zero. The resulting fall in disposable income will bring about some automatic correction of the external deficit, but it will also reduce domestic demand. To restore internal balance the expenditure-reducing effect of budget balancing needs to be supplemented by expenditure-switching policies such as real depreciation, tariffs, or quotas. Thus the first point to be made is that budget cutting requires for full employment an accommodating real exchange rate policy that would bring the economy to a point such as $B$. As the figure is drawn, there is current account surplus at $B$. But all that is essential is that $B$ represents a lower current account deficit than $A .^{2}$

The importance of the argument that budget balancing needs to be accompanied by a move toward external balance is reinforced by the political dynamics of budget cutting. It is unlikely that Congress will cut the budget in economic conditions that would bring about an almost certain recession. Hence there is a need to pave the way for budget cuts by strengthening the external balance ahead of time. Because adjustment lags are important, a successful strategy involves depreciation years ahead of actual budget cutting.

A second point focuses on external debt dynamics, and in particular on the external debt-GNP ratio. To avoid overindebtedness, which would bring with it ultimate but sudden credit rationing and very costly adjustment on short notice, much as is happening to less developed countries now, the noninterest current account balance must swing toward surplus. With a noninterest surplus the debt-GNP ratio ultimately settles down when the surplus is just sufficient to service debt at a rate that is determined by the growth rate-real interest rate differential. This kind of argument is familiar from the literature on LDC debts and has

2. There is also room for real interest rate reductions to achieve this objective. Indeed, in well-functioning markets the long-term real interest rate would decline in anticipation of future budget cuts. 
Table 1. The U.S. External Balance and Net Investment Position, 1982-86

Billions of dollars unless otherwise indicated

\begin{tabular}{|c|c|c|c|c|c|}
\hline Item & 1982 & 1983 & 1984 & 1985 & 1986 \\
\hline International investment position ${ }^{\mathrm{a}}$ & 136.2 & 88.5 & 4.4 & -107.4 & $-232.0^{\mathrm{b}}$ \\
\hline Current account & -9.1 & -46.6 & -106.5 & -117.7 & -140.6 \\
\hline Noninterest current account ${ }^{c}$ & -37.8 & -71.4 & -125.3 & -142.9 & -163.5 \\
\hline NICA as percent of GNP & -1.2 & -2.1 & -3.3 & -3.6 & -3.9 \\
\hline
\end{tabular}

Source: U.S. Department of Commerce, Bureau of Economic Analysis, Survey of Current Business, various issues.

a. U.S. assets abroad less foreign assets in the United States at the end of the year.

b. Preliminary.

c. The current account less net receipts of investment income in the balance of payments accounts.

been used with foresight in discussions of the dollar exchange rate by Paul Krugman. ${ }^{3}$

The argument can be formulated in terms of the equations for full employment and the accumulation of external debt. Let $b$ be the ratio of net external liabilities to GNP, $r$ the real interest rate, and $y$ the growth rate of output. The ratio of net external liabilities (debt, for short) to GNP increases as follows:

$$
\dot{b}=(r-y) b-x,
$$

where $x$ is the ratio of the noninterest current account to GNP.

Table 1 shows recent data for U.S. net foreign assets and for the current account and the noninterest current account.

Net external liabilities are still small, amounting to about 6 percent of GNP. But the noninterest current account adds currently at a rate of nearly 4 percent of GNP a year to these deficits so that external debt is rising by about this same percentage of GNP in $1986 .{ }^{4}$

Figure 2 suggests alternative time paths of the real exchange rate and external debt. The vertical axis is the real exchange rate, as in figure 1. The ratio of external debt to GNP is on the horizontal axis. The figure

3. Paul R. Krugman, “Is the Strong Dollar Sustainable?' in Federal Reserve Bank of Kansas City, The U.S. Dollar: Recent Developments, Outlook and Policy Options (FRBKC, 1985), pp. 103-32.

4. Note the peculiarity in the relation of net external assets and investment income. Even though the United States in 1986 was already a net debtor the investment income balance was still positive. In part this reflects inadequacies of the net investment position, in part the composition of assets and liabilities. For example, U.S. claims on LDCs carry much higher interest rates than U.S. government bonds held by foreign central banks. 
Figure 2. Alternative Adjustment Paths

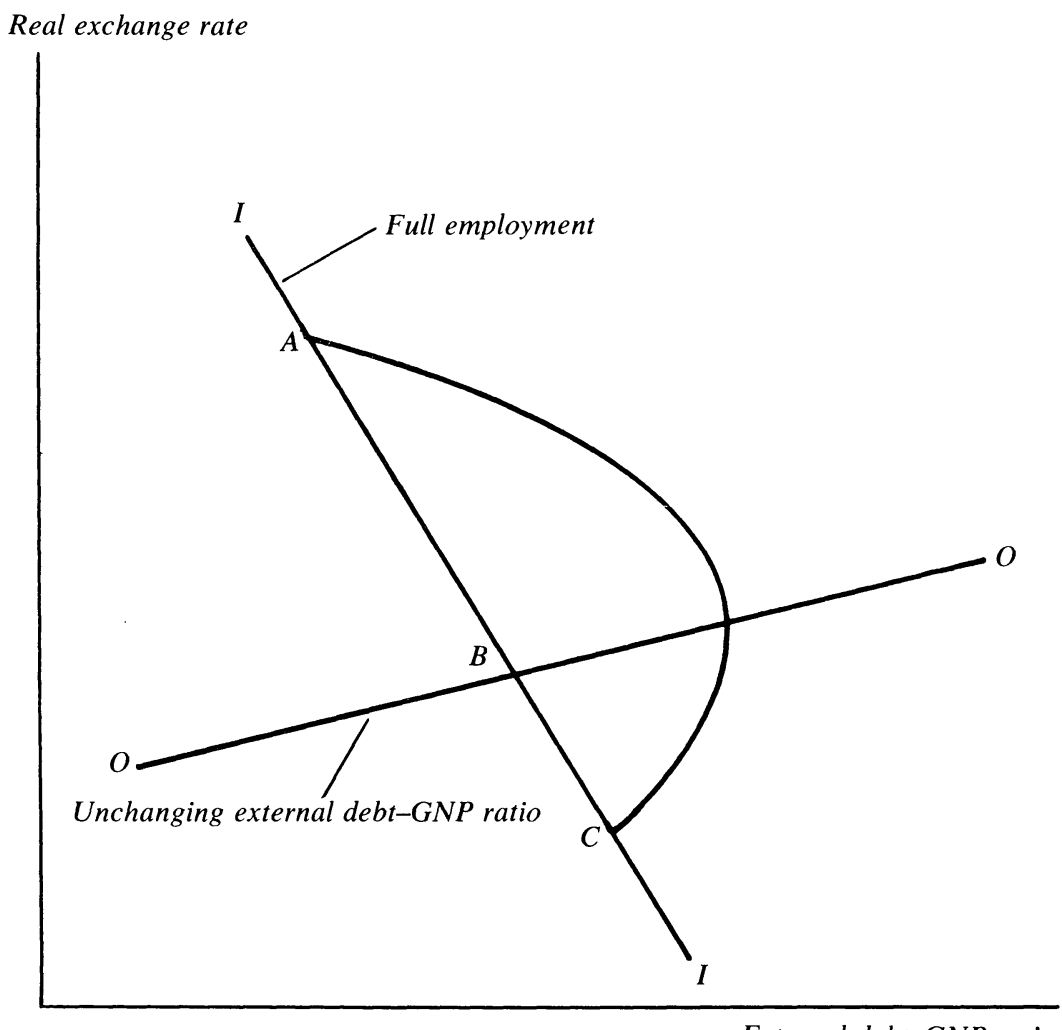

External debt-GNP ratio

shows internal balance or full employment (given appropriately varying combinations of real interest rates and the full-employment budget) along the II schedule. The effect of external debt on aggregate demand is negative - that is, the curve slopes down-because of the implied reduction in disposable income..$^{5}$ Along the $O O$ schedule the external debtGNP ratio is constant. It is rising in the area above $O O$. The $O O$ schedule is drawn for the case in which the growth rate of income exceeds the real interest rate so that a debtor nation can run a deficit on noninterest current account and still reduce the ratio of debt to GNP.

5. The exact dynamics of this effect would have to be studied taking account of the timing between wealth effects and spending. 
From an initial point of internal balance like $A$ the economy will have to move over time to $B$. If the real exchange rate is slow to move, the risk is that the real exchange rate will have to overshoot ultimately to a point like $C$ in order to sustain full employment while reducing the external debt relative to GNP. Too high an exchange rate in the early stages of borrowing thus leads to overindebtedness that ultimately forces the economy for some time to points southeast of $B$.

The policy discussion of full employment and the external balance involves two questions. First, do asset markets look far enough ahead, or do they allow disequilibria to build up that ultimately are solved by a crash? If asset markets are not farsighted, one cannot be confident that real exchange rates and long-term interest rates anticipate the ultimate correction in the budget and the noninterest current account. Real depreciation is too sluggish, and long-term interest rates remain too high. Second, if asset markets are farsighted, is the adjustment path they impose the best one, taking into account macroeconomic facts such as lack of full wage-price flexibility, potential real wage rigidities, and political constraints on the use of fiscal policy? In either case, the external balance and long-term real interest rates require policy intervention.

\section{The Nonissue Arguments}

The need for active policy intervention has been challenged on a number of grounds. The most obvious argument is that the necessary correction in long-term real interest rates and the external balance is already under way. With rising inflation and expectations of increasing inflation, the long-term real interest rate has in fact declined. The real depreciation has already been significant, and all that is required is patience: the adjustment in the external balance is already under way. In this view the emphasis now must be on budget correction so as not to risk a crowding out of investment when strong trade improvements collide in a fully employed economy with domestic demand that remains overly strong. Franco Modigliani has argued along these lines, especially in pointing out that at full employment the external balance correction that is under way must come at the expense of investment unless budget cuts reduce consumption. ${ }^{6}$

6. See Franco Modigliani, "In the Shadow of the Budget Deficit," New York Times, March 1, 1987. 
Another argument, based primarily on capital gains on U.S. stocks and real estate over the past two years, suggests that there is no need to generate a noninterest current account surplus. Steady capital gains permit a portion of U.S. assets to be sold off steadily without risking a decline in wealth and the standard of living. But the question is why there should be a steady real asset appreciation of a sufficient magnitude to finance the gap between spending and income. One reason might be the nature of international capital markets. One could argue that many countries, especially Japan, remain largely undiversified, with too small a portion of U.S. assets in their portfolios. Hence many years of deficits can still be easily financed.

Indeed, it is precisely the opening of capital markets and the resulting improvement in the market value of U.S. assets that justifies the overspending. Just as a terms-of-trade improvement would justify increased spending, so do the capital gains from a favorable shift in world demand for a country's assets. The difficulty with this argument is that it amounts to a sizable gamble. If portfolio holders one day do get satiated with U.S. assets, or simply want to slow down the rate of addition to their portfolios, there will have to be a much larger correction in the real exchange rate. The reason is that the lack of competitiveness over a long period of time will have led to disinvestment and hence a lack of capital, skills, and organization in all forms that would make it possible to resume net exports at short notice. If central bank intervention rather than private saving has already been financing a major part of the U.S. trade deficit, skepticism about the ability to finance extended deficits becomes even more pressing.

Some people recognize that the current budget and external positions are unsustainable but argue that correction is not required because, at some point, a shift to sharply inflationary policies will liquidate the debts. The budget constraint need not hold, and hence it would be a mistake to live by it. This argument is offered particularly to mark the difference between dollar debts of LDCs that those debtors cannot inflate away and the special opportunity of the United States. But the argument encounters the difficulty that the necessary inflation policy may be very expensive. A collapse of the dollar would certainly be inevitable and that collapse, while reducing the burden of debts, would also worsen the terms of trade. The extra inflation would be so costly that it looks like an implausible policy design. A more credible scenario relies on a reduction in real interest rates to near-zero levels worldwide. Such a 
reduction would mean that debt problems disappear provided there is moderate growth and that noninterest current account deficits can be trimmed to moderate levels.

Another view acknowledges the ultimate need for adjustment in the external balance, but argues that the adjustment will come automatically when budget correction takes place. The increase in taxes will cut domestic demand. The reduction in spending will free goods for export and reduce import spending. The direction of these effects is certainly correct. But two questions remain. One is whether the spending cut is sufficient to restore external balance, including debt service. The other concerns full employment. If spending is cut without adjustment in the real exchange rate there is bound to be unemployment. What is needed, as I have already explained, is both expenditure-reducing and expenditure-switching policies. Budget cutting by itself cannot satisfy the $t w i n$ objectives of full employment and external balance. Real interest rates and the real exchange rate will have to adjust to accommodate the increase in national saving at full employment.

A final argument against active policy is that the market will, when the time comes, make all adjustments required to assure full employment. Herbert Stein has made this argument:

Does anyone know an optimum rate of the trade deficit other than what emerges in the market? I think not. Certainly the optimum rate is not zero. A cliche of these days is that a trade deficit of the present size cannot go on forever. This is not axiomatically true, but it is probably true. That does not, however, give any guidance . . . if something cannot go on forever it will stop. Government action to stop it is not required. ${ }^{7}$

The argument is impeccable if one believes that markets always get things right. The question remains whether asset markets do get it right and whether they have done so in this instance. This is the point made by Stanley Fischer. ${ }^{8}$

\section{A Forecast for Net Exports}

It is beyond the scope of this paper to develop persuasive counterarguments and demonstrations for each of these positions, which, in

7. Quoted from Herbert Stein, "Leave the Trade Deficit Alone," Wall Street Journal, March 11, 1987. See also Stein, "Thoughts on Exchange Rates and All That," AEI Economist (November 1986), and "A Primer on the Other Deficit," AEI Economist (March 1987).

8. See Stanley Fischer, Comments on "Symposium on Exchange Rates, Trade, and Capital Flows," BPEA, 1:1986, pp. 227-32. 
combination, suggest that the trade problem may not be as bad as it appears. A rebuttal would include the list of arguments that suggests the need for early and large adjustment in the noninterest current account. The most important of these is the risk that asset markets are not farsighted and that as a result the United States is disinvesting in precisely those industries whose existence would ease adjustment and reduce the ultimate need for a significant overshooting of exchange rates.

Instead of making a detailed rebuttal, I will investigate whether the current level of the dollar is in some fundamental way appropriate. This requires identifying the main determinants of net exports and asking whether a major improvement in net exports can be expected at the current level of the dollar, taking into account lags. In a regression reported below, the determinants of U.S. net exports are the real exchange rate, relative levels of real total spending in the United States and other industrialized countries, and a time trend. The following were the results, using quarterly data from 1975 through 1986 and with $t$-statistics in parentheses: ${ }^{9}$

$$
\begin{aligned}
& N E T=90.0-5.96 \log \left(P / e P^{*}\right) \\
& \text { (7.86) } \quad(-3.78) \\
& \text { - } 12.23 \log \left(D / D^{*}\right)-0.04 \text { Time, } \\
& (-3.68) \\
& \bar{R}^{2}=0.96 ; \text { rho }=0.43 ; \text { standard error }=0.28,
\end{aligned}
$$

where NET is nominal U.S. net exports in the national income accounts as a percent of GNP, $P / e P^{*}$ is a distributed lag of the relative valueadded deflator in manufacturing, and $D / D^{*}$ is relative levels of real total spending.

The regression shows that real exchange rates and relative spending levels are significant determinants of net exports. A 16 percent real depreciation increases net exports by 1 percent of GNP, as does an 8 percent rise in the relative level of foreign real spending. There is an adverse time trend in net exports that leads over a six-year period to a deterioration in net exports by 1 percent.

9. The real exchange rate measure is the International Monetary Fund's relative valueadded deflator in manufacturing reported in International Financial Statistics. The index of the relative levels of real gross domestic spending was calculated as follows: for the United States, real gross domestic spending; for the rest of the world, a weighted average index for the non-U.S. OECD constructed from interpolated annual data. The weights are the OECD GNP shares. 
Figure 3. U.S. Net Exports, 1982:1-1986:4, and Forecasts under Alternative Foreign Growth Rates, 1987:1-1992:4

Percent of GNP

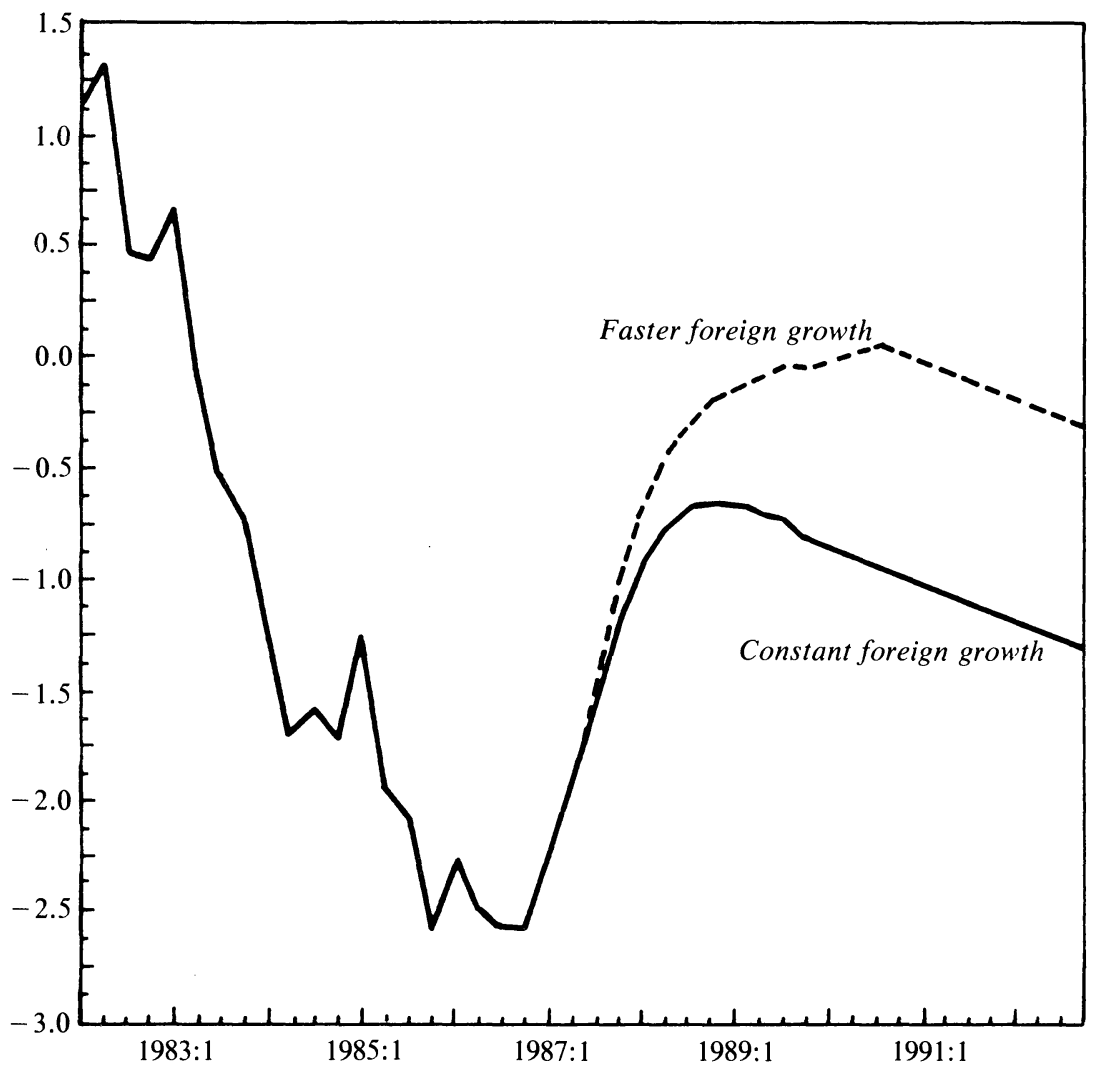

Sources: Actual data are from Survey of Current Business, vol. 66 (July 1986), and vol. 67 (April 1987). Forecast is based on equation 2 in the text.

a. Quarterly data. The forecast is for two alternative scenarios. In both cases, the real exchange rate is held constant at the level of 1987:1. The faster foreign growth case assumes a 2.5 percent differential growth rate of U.S. and foreign real spending for a three-year period. The constant foreign growth case assumes constant relative levels of real spending.

Figure 3 uses a forecast from this regression under two alternative scenarios. In one case the real exchange rate is held at the level of the first quarter of 1987 and relative levels of spending are held constant. This scenario highlights that a significant improvement in net exports stemming from the lagged effects of dollar depreciation is to be expected. But the forecast also shows that net exports remain in deficit and that by 
the early 1990s that deficit comes to exceed 1 percent of GNP. In terms of debt dynamics this scenario is not consistent with a convergence toward a stationary ratio of external liabilities to GNP.

Equation 2 suggests that the current level of the dollar is appropriate only if there is to be a substantial shift in relative spending levels. The "faster foreign growth" scenario shown in figure 3 assumes a 2.5 percent differential in the growth rate of real spending for a three-year period. This cumulative growth differential is enough to bring the U.S. external balance near zero at least for a while. But since there is little prospect that Europe and Japan will double their growth rates of demand over the next three years, the growth differential would have to come primarily from slower U.S. growth. While that would help solve the external balance problem, it does not deal with the unemployment issue. Exchange rate or commercial policy must help bring about a correction of the external balance. The balance of the paper assesses the trade-offs involved in using alternative instruments to accomplish this objective.

\section{The Impact of a Uniform Tariff}

First I consider the impact of a tariff that is levied at a uniform rate, say 10 percent, on all merchandise imports. It is helpful to start the analysis in a classical setting with full wage-price flexibility and full employment. I later add short-term macroeconomic detail.

\section{A CLASSICAL SETTING}

The determination of the real exchange rate or the terms of trade and the real interest rate under conditions of perfect competition and full wage-price flexibility are at the center of the classical model.

A tariff introduces a wedge between the relative prices faced by home residents and the rest of the world. A crucial assumption in the analysis of tariffs is the use of the proceeds. I assume that the government uses the proceeds to correct the budget deficit. Consequently an increase in the tariff will have an income effect equal to the increase in tariff revenue. At a given world price ratio the imposition of a tariff raises the domestic relative price of imports and creates an excess supply of foreign goods since both income and substitution effects lead to a reduction in demand. The effect on the demand for domestic goods is uncertain since income 
and substitution effects work in opposite directions. If these effects exactly cancel, it is readily shown that equilibrium interest rates must fall and the world relative price of domestic goods must rise.

The classical model thus shows the role of the relative size of income and substitution effects. Since the tariff revenues are used to reduce the budget deficit, the tariff represents a combination of expenditure-reducing and expenditure-switching policies. Strong income effects tend to leave relative world prices unchanged and lead to a large decline in the world real interest rate. By contrast, strong substitution effects bring about a larger real dollar appreciation and relatively less of a decline in the real interest rate. Uncertainty about the relative size of income and substitution effects carries over to a short-term macroeconomic setting.

The real appreciation or terms-of-trade improvement that occurs when substitution effects dominate is the way in which the rest of the world is made to pay part of the tariff. The idea of an optimum tariff is based on exactly this fact. A large country will benefit by adopting a tariff so as to improve the terms of trade. At the optimum tariff the welfare cost of misallocating resources exactly offsets the gains from the transfer of resources implicit in the terms-of-trade improvement.

\section{A MACROECONOMIC SETTING}

The macroeconomic setting is distinguished from the classical model by the assumption of at least potential wage-price stickiness and stickiness of the real wage. There is a possibility of transitory unemployment, and there is room for strategic considerations in price setting. Likewise, wage setting need not be geared exclusively to full employment. ${ }^{10}$ With real wage stickiness there is even a possibility of long-run unemployment.

The effects of a tariff on output, prices, the trade balance, interest rates, and the exchange rate are of particular interest. A tariff might lead to an undesirable combination of changes, including a decline in output, higher interest rates, higher prices, and an appreciation of the currency. Unfortunately the effects of a tariff are not predictable in general terms because monetary policy here and abroad, foreign fiscal policy, and

10. See Edward Tower, "Commercial Policy under Fixed and Flexible Exchange Rates," Quarterly Journal of Economics, vol. 87 (August 1983), pp. 436-54, for an early macroeconomic discussion. See also Robert A. Mundell, International Economics (Macmillan, 1968). 
wage- and price-setting behavior influence the results decisively and thus leave open a wide range of outcomes. The effect of a tariff depends also on details of money demand and aggregate demand on which there is little or no empirical information.

To make headway I assume that monetary policy follows a rule of stabilizing nominal income:

$$
p+y=c,
$$

where $p$ and $y$ denote the logarithms of producer prices and output and $c$ is the policy-determined constant level of nominal income. The goods market equilibrium is shown in equation 4 and price dynamics in equation 5:

$$
\begin{gathered}
y=d(e+T-p)-\mathrm{g}\left(i^{*}+\dot{e}\right), \\
\dot{p}=v\left(y-y^{\prime}\right),
\end{gathered}
$$

where $y^{\prime}$ denotes full-employment output. Substituting the nominal income rule in equations 4 and 5 yields equations for the rate of inflation and the rate of depreciation, given the world interest rate $i^{*}$. For the case where substitution effects dominate, it can be shown that a tariff will lead to an immediate appreciation of the exchange rate, an unchanged level of real interest rates, and no effect on output.

The exchange rate appreciation only partially offsets the effect of the tariff on relative prices, but the offset is more complete the smaller the income effect of the tariff. Demand can be sustained at the full-employment level by an exchange rate appreciation that crowds out the expenditure-switching effect of the tariff. Of course, in a model of the world economy this assessment of the effects cannot be complete since there is a change in world saving.

To consider an extension in which a tariff has long-run effects on output, I explore the case where the consumption wage is rigid. ${ }^{11}$ If firms use markup pricing and if wages rise when the cost of living increases, we get a model of inflation different from equation 5, in which inflation will depend on the relation between the consumer price level and producer prices:

11. The case of protection with fixed real wages has been explored by $S$. van Wijnbergen, "Tariffs, Employment and the Current Account: On the Macroeconomics of Real Wage Resistance,' International Economic Review (forthcoming). 


$$
\dot{p}=u(q-p) ; \quad q=(1-a) p+a(e+T),
$$

where $q$ is the consumer price level. Now a tariff will have effects on exchange rates and prices. There will be an impact on long-run output because of real wage rigidity. ${ }^{12}$

In this new setting the tariff works through two separate channels. On the demand side there are the income and substitution effects. But now, in addition, there is a constraint on the consumption wage, which is fixed. When the tariff reduces the consumption wage, at a given world relative price, there needs to be an offsetting gain in the terms of trade to restore cost-price balance. This latter effect constrains the long-run equilibrium of the model and leads to a reduction in long-run equilibrium output and employment. The mechanism is the following. The tariff leads immediately to some appreciation. With dominant income effects the appreciation brings about excess demand and an initial rise in output. But from the cost side there is now inflation because the appreciation will not have been sufficient to compensate for the reduction of the consumption wage due to the tariff. Over time wages and home prices are rising. The exchange rate further appreciates until a new equilibrium is reached in which the consumption wage has returned to the initial level, with higher prices and an appreciation of the exchange rate. The tariff is fully paid by the rest of the world, but output and employment have declined.

A nominal income rule for monetary policy rules out important money market effects. Output effects therefore stem only from real wage rigidities and are absent if relative prices can change without effects on labor supply. But if the money supply is not sufficiently accommodating there is a possibility that price increases induced by the tariff raise interest rates and lead to real appreciation beyond what is required to offset the tariff. Then output may actually decline. A Data Resources, Inc., simulation makes the point.

DRI MODEL SIMULATION RESULTS

The DRI model was simulated in 1985 for the case of a temporary and declining import surcharge. The tariff starts at 20 percent and declines

12. The equations are, respectively, $\dot{p}=v a(e+T-p)$ and $\dot{e}=(1 / g)[p(1-d)$ $+d(e+T)]-i^{*}$. 
Table 2. Simulation of a Temporary Import Surcharge ${ }^{a}$

Difference from baseline projections

\begin{tabular}{lrrrr}
\hline & \multicolumn{4}{c}{ Year } \\
\cline { 2 - 5 } \multicolumn{1}{c}{ Item } & \multicolumn{1}{c}{1} & \multicolumn{1}{c}{2} & 3 & 4 \\
\hline Federal surplus (billions of dollars) & 71 & 50 & 15 & -14 \\
Current account (billions of dollars) & 50 & 59 & 26 & -3 \\
Real GNP (percent) & -0.2 & -0.8 & -1.1 & -0.8 \\
Treasury bill rate (basis points) & 15 & 40 & 35 & -15 \\
Money supply (M1, percent) & 0.9 & 0.5 & -0.2 & -0.5 \\
Consumer price index (percent) & 0.8 & 0.8 & 0.4 & 0.0 \\
Real exchange rate appreciation (percent) & 1.6 & 3.9 & 2.1 & -1.4 \\
Export volume (percent) & -0.2 & -1.7 & -2.6 & -1.3 \\
\hline
\end{tabular}

Source: Christopher Caton, "The Effects of a Temporary Import Tariff," in Data Resources, Inc., Review of the U.S. Economy (DRI, March 1985), table 3.

a. Simulation of a uniform tariff on all imports including oil, assuming no foreign retaliation and one-half absorption of the tariff by foreign suppliers. The tariff is 20 percent the first year, 15 percent the second, 7 percent the third, and zero the fourth.

over the following three years to 15 percent, 7 percent, then zero. The simulation assumes explicitly no foreign retaliation and a one-half absorption of the tariff by foreign suppliers. The tariff is uniform and without exemption on all imports, including oil. The policy assumption is that there is modest monetary accommodation, not exceeding a 1 percent deviation from the baseline case. The difference from baseline projections is shown in table 2.

In the early stage of the tariff there is an increase in interest rates and a currency appreciation. Real GNP declines because the fiscal and interest rate effects dominate the substitution effects. The appreciation implies that the gain in competitiveness in the final year of the tariff is quite minor and that, accordingly, output declines throughout the tariff episode. An important aspect of the tariff is that it reduces exports because the real exchange rate appreciates.

The simulation highlights one essential feature of the tariff, namely, the persistent favorable effect on the budget. Because the proceeds of the tariff reduce the budget deficit, they slow down debt accumulation and hence reduce the long-run deficit relative to the baseline simulation. This revenue feature has led William Branson to advocate tariffs as a means to improve the external balance and the budget. ${ }^{13}$

13. William H. Branson, Comments on "Macroeconomics and Protection," in Robert M. Stern, ed., U.S. Trade Policies in a Changing Economy (MIT Press, 1987), pp. 13136; and Branson and James Pearce, "The Case for an Import Surcharge" (Princeton University, March 1985). 


\section{Tariffs versus Depreciation}

Both the theoretical analysis of the tariff under a nominal income rule and the simulation results emphasize that a tariff brings together expenditure-reducing and expenditure-switching features. It thus can improve the budget and the current account at the same time. But there are costs when monetary policy is not fully accommodating and when real wages are sticky. How do the costs and benefits of a tariff compare with those of depreciation?

Both a tariff and depreciation raise the relative price of imports at home, but depreciation offers no beneficial fiscal effect. Where the tariff yields revenue, the depreciation leads to a terms-of-trade deterioration. Later I will look at a depreciation combined with an increase in taxes. Now I consider depreciation alone, brought about by an increase in the nominal income target. In terms of equations 3 through 5 there is now an increase in $c$ to $c^{\prime}$. Figure 4 shows the effects. The vertical axis is the exchange rate expressed as the unit of domestic currency per unit of foreign currency. The $\dot{p}=0$ schedule shows the price level at which, for a given nominal income target, output is at the full-employment level so that there are no inflationary pressures. To the right, prices are too high, and hence output too low, so that there is deflation. To the left, there is inflation. Along $\dot{e}=0$ (drawn for the case where $d<1$ ) home and foreign interest rates are equal, given the nominal income target. An increase in prices lowers output (given the target) relative to demand. To eliminate the excess demand for domestic goods the exchange rate must appreciate, thus diverting demand to imports and reducing net exports. The initial full-employment equilibrium is at point $A$.

An expansion in the nominal income target moves the $\dot{p}$ and $\dot{e}$ schedules to $\dot{p}^{\prime}$ and $\dot{e}^{\prime}$ as shown in figure 4 . The new long-run equilibrium is at $A^{\prime}$, where we have an equiproportionate increase in the exchange rate and prices. But in the short run, before prices change, the economy moves to point $B$ on the stable trajectory $K K$. The exchange rate, as is common in models of short-run price stickiness, will overshoot. At $B$ there is an expansion of output and employment beyond full employment and an improvement in the external balance. Inflation sets in and the advance in real output is gradually eroded. The nominal interest rate, which at $B$ had declined, now starts rising back to the world level. The low (though 
Figure 4. The Shift to a Higher Nominal Income Target

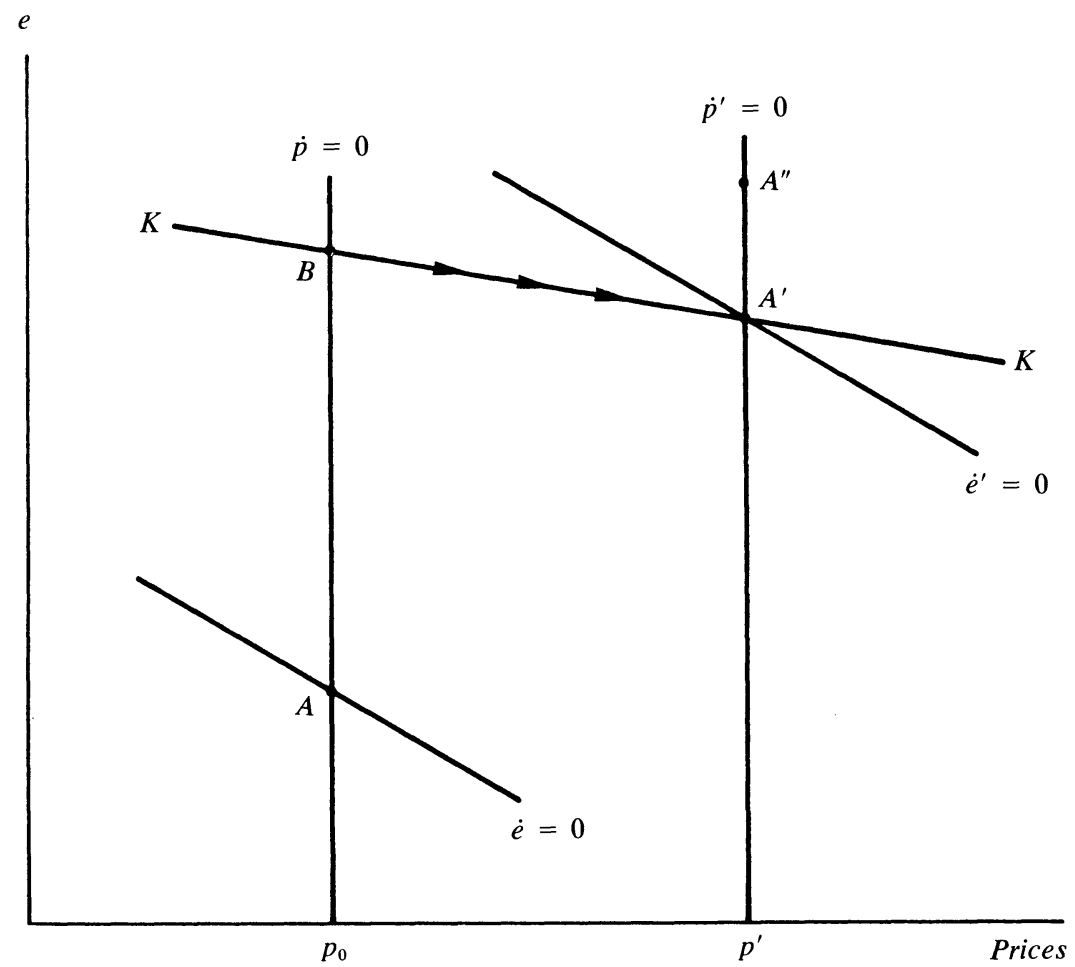

rising) level of the home interest rate is offset by gradual appreciation as the economy moves from $B$ to $A^{\prime}$. Thus in this long-run classical economy depreciation has only transitory benefits. It does lead to a transitory improvement in the external balance and to a gain in output; but these gains are not sustained because the increase in inflation collides with the nominal income target and leads to a gradual erosion of the gains in competitiveness and net exports.

Consider next the case where the depreciation policy is supplemented with an increase in taxes. Now there will be a long-run real depreciation to ensure that the reduction in domestic demand stemming from reduced disposable income is offset by the crowding in of net exports. The adjustment path is as shown in figure 4 except that the exchange rate will depreciate even further in the short run. In the long run the economy will end up at a point like $A^{\prime \prime}$. 
It is worth repeating that a depreciation would not have the beneficial fiscal effects of a tariff. With a depreciation the terms of trade deteriorate and thus transfer real income abroad rather than to the budget. Only for the private sector is the income effect the same as in the case of a tariff. Despite the absence of the beneficial fiscal effect, depreciation offers several advantages over a tariff. The first is that depreciation represents an export subsidy while a tariff amounts to an export tax by way of the induced currency appreciation. The import sector will benefit under each policy, but the consequences for the export sector are quite different. Under a tariff the export sector is taxed through the appreciation of the exchange rate. By contrast a depreciation is a subsidy for exports. Depreciation reduces imports and raises exports, while a tariff reduces both, though with a larger impact on imports.

Another disadvantage of a tariff is that it is bound to invite retaliation or emulation, especially if it is permanent. Joan Robinson has commented on the choice between depreciation and the tariff as alternative beggarmy-neighbor policies:

All expedients are subject to the objection that they are calculated to promote retaliation; indeed this is the very nature of the beggar-my-neighbor game. Which expedient is the least dangerous from this point of view will depend upon general political considerations. ${ }^{14}$

Depreciation, unlike tariffs, is unlikely to lead to emulation. But if it does, that is strictly for the better. A depreciation would under the most favorable conditions degenerate into competitive interest rate cuts as each country seeks to maintain and improve its competitiveness by trying to push capital out. At the present juncture of the world economy, that would be a very favorable outcome. Needless to say, competitive interest rate cutting would make a major, direct contribution to budget balancing. ${ }^{15}$

The third disadvantage of a tariff is that if it is permanent, it represents an inefficient means of achieving a long-term improvement in the budget and the external balance. The resource costs of balancing the budget in this way, not even counting the risk of retaliation, are significant, and

14. See Joan Robinson, Essays in the Theory of Employment (Macmillan, 1937), pp. $227-28$.

15. It is, of course, possible that foreign countries respond to a U.S. tariff by cutting their interest rates. But this seems a less characteristic response than a tariff war. 
the same objectives can be attained in a more cost-effective way by a depreciation and increases in general taxation. Of course, that judgment has to stop short of being categorical because budget balancing in the absence of a tariff is unlikely to be done with neutral lump-sum taxes. Increased income taxes are also distortionary, and it is conceivable that there are much worse budget-balancing packages than a permanent tariff. Even so, the balance of arguments favors depreciation both because of the potentially favorable short-term macroeconomic effects and because broad taxes are more efficient than equal-revenue trade taxes.

\section{Uniform Tariffs versus Selective Policies}

An alternative to a uniform tariff is a selective system of trade intervention such as a tariff on manufactures only, a tariff on Japanese goods only, a voluntary export restraint exercised by countries with bilateral surpluses, or the auctioning of quotas. Each of these policies will have macroeconomic effects. Like a tariff they will tend to raise import prices and will shift demand toward domestic goods. In the same way as a tariff they will have an income effect that may or may not favor the budget, but certainly reduces aggregate demand. The direction of macroeconomic effects is thus the same as it would be in the case of a tariff, but the selectivity and particulars of the intervention add to the complications.

For example, an auctioning of quotas captures the revenue for the government in the same way as a tariff would. But the price effects differ and so do the current account effects. If, for example, the quota applies to the number of automobiles, one would expect an upgrading of imported automobiles with a resulting effect on price. Japanese or European cars might come ahead at the expense of Korean cars, and the result could be a net increase in import spending. The price effects of a quota would depend on the particular market structure. It is certainly conceivable that a quota could be much more inflationary than an equal-revenue tariff.

A voluntary export restraint differs from the quota auction in that foreign firms can raise their prices and collect the rents rather than compete them away at auction. Restraints therefore do nothing for the 
budget and need not even improve the trade balance. They are presumably the worst kind of protection from a macroeconomic perspective.

Geographic discrimination in protection is another direction for selectivity. The obvious criterion would be to place a tariff on those countries that have a bilateral surplus with the United States. The difficulty is that most problem debtor countries, including Brazil, have trade surpluses with the United States. Imposition of a tariff would almost certainly lead to a suspension of interest payments and hence to a deterioration in the current account. Asian newly industrialized countries have a limited ability to absorb trade deterioration before they too become problem debtors, and Europe would certainly retaliate against protective tariffs. That leaves Japan. A tariff on Japan would improve U.S. terms of trade and redistribute income from Japan to the U.S. budget. But would extra imports from Europe and Korea fill the gap left by a tariff on Japan? If the substitutability were high, the benefits might turn out to be too small to warrant such a massive confrontation.

It is unlikely that selective tariffs targeted on countries or on groups of goods can efficiently cope with the external balance and employment problems. But in the context of a policy package of exchange depreciation there may be room for such special revenue tariffs as an import duty on oil.

\section{Concluding Remarks}

Depreciation, tariffs, and quotas differ significantly in their macroeconomic effects, particularly in their impact on inflation, in their contribution to budget balancing, and in their sectoral impacts. Tariffs are effective in balancing budgets and may be less inflationary than depreciation. But they carry the disadvantage of inefficiency in resource allocation, particularly when they are permanent, and-in all likelihood the strongest macroeconomic argument against their use-they present an open invitation for emulation and retaliation.

By contrast a policy of cutting interest rates to bring about depreciation, while raising taxes at the same time, may be the most effective means to trigger overdue foreign growth policies. If world interest rates could be cut, there would be much less need for large dollar depreciation to solve the budget and the external balance problem. But interest rates 
will not be cut abroad unless clean beggar-my-neighbor depreciation forces Europe and Japan to respond in kind.

It is often argued that a policy of depreciation could turn out to be self-defeating. Loss of confidence in Europe and Japan would lead to a fall in investment, adding to the depressing effects of lower exports. The cumulative decline in income abroad, especially given accelerator effects, might be so large that in the end U.S. exports would be lower, not higher. Not only would the United States wreck foreign economies by aggressive depreciation, it would hurt even its own interests. Hostage to the accelerator, the United States would be best advised to halt any beggar-my-neighbor policies until foreign economies acquire more vigor to withstand the necessary adjustments in the world economy. If the situation is in fact all that precarious, the case for fiscal expansion abroad and for lower interest rates becomes even stronger. 